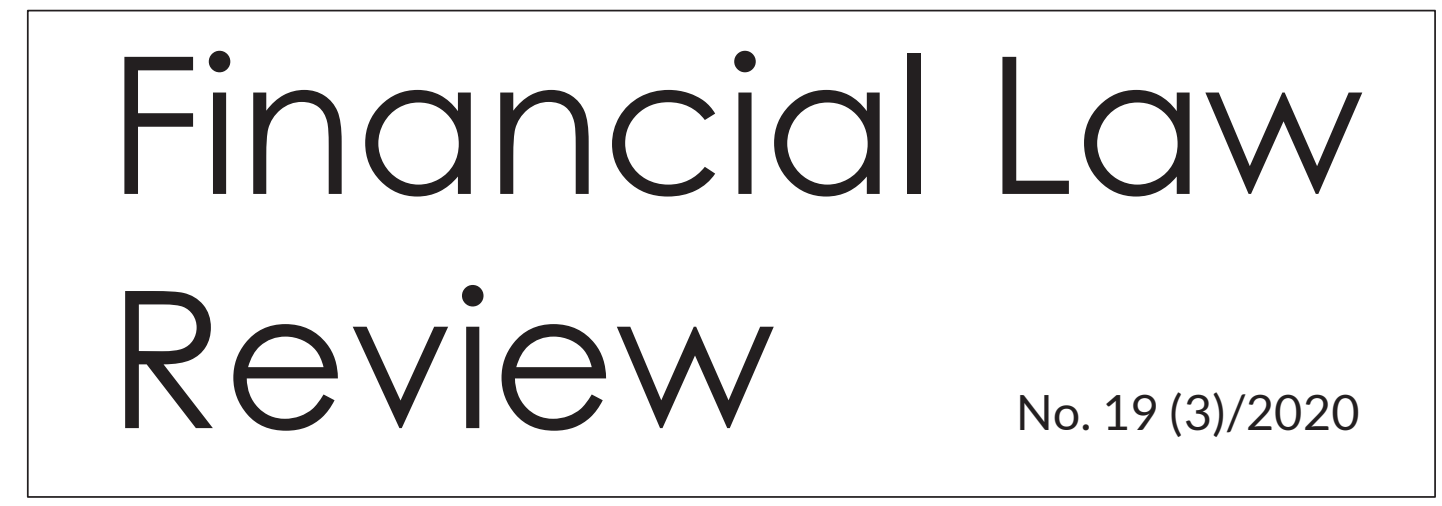

UNIVERSITY OF GDAŃSK • MASARYK UNIVERSITY • PAVEL JOZEF ŠAFÁRIK UNIVERSITY • UNIVERSITY OF VORONEZH http://www.ejournals.eu/FLR

Maria Mardasova*

\title{
FINANCIAL SUPPORT TO LOCAL BUDGETS FROM OTHER BUDGETS IN RUSSIA AND SOME FOREIGN COUNTRIES
}

\begin{abstract}
The article is devoted to the consideration of relations on providing financial support, the so called inter-budget transfers, to local budgets from other budgets of the budget system of the Russian Federation. The acceptance of the independence of local self-government with the adoption of the Constitution of the Russian Federation in 1993 made it necessary to implement legal regulation of relations in the field of financial support to the activities of municipalities.

The article describes the process of reforming the regulatory framework in the field of relations for the provision of inter-budget transfers to local budgets. The author conducts comparative analysis of inter-budgetary relations for providing financial support to municipalities with a number of European States (the Czech Republic, Poland, the Republic of Lithuania, and Slovakia) and also highlights similarities with Russian legal regulation.
\end{abstract}

Key words: financial support, inter-budget transfers, local budgets, subvention, grant, subsidy, interbudget relations, budget system

JEL Classification: K20, H61, H72, H77

\footnotetext{
* Lecturer of Financial Law Department, Faculty of Law, Voronezh State University (Russia, Voronezh), Candidate of legal sciences. E-mail: m.mardasova@yandex.ru.
} 


\section{Introduction}

The Russian Federation recognizes the autonomy of local self-government, which has its own financial resources. However, this was not always the case.

Since the 1970s, within the developed world, there has virtually been no large country that has not witnessed some degree of decentralization. Many countries in central Europe were engaged in signifi cant decentralization on or before their accession to the EU [RodriguezPose, Ezcurra 2009: 6]. A number of transition countries throughout Eastern Europe and Central Asia have also been decentralized [DablaNorris 2006: 104].

Thus, in the Czech Republic, a municipality is the main administrative-territorial unit, for which it must have both its own property and financial resources to ensure the functions of self-government [Marková 2012: 9-10].

In the Republic of Lithuania a municipality is an administrative unit of a state territory whose community has the right of self-government guaranteed by the Constitution [Art. 2 of the Act no. I-533/1994]. At the same time, an important part of the property of a municipality is the fi nancial resources necessary for the realization of local self-government [Sudavicius 2017: 57].

The transformation in Poland started with establishing the real self-government in 1990, on the commune level, which became a test ground for rules and methods of $f$ nancing the public tasks carried out by the self-government, its status and participation in the public finance system [Sowiński 2017: 27].

The Russian Federation is no exception. The first steps in the direction of decentralization are connected with the adoption of the Act no. 1550-1/1991. A little later, the autonomy of local self-government was proclaimed in the Constitution of the Russian Federation in 1993.

The most important stage in the legal regulation of local self-government was the ratification by Russia of the European Charter of Local Self-Government of 1985 by the Act no. 55-FZ/1998. The fundamental principle of the Charter is the ability to freely dispose of resources acquired by the local community, the disposition of funds in favor of communities in need of finance, and the probability of granting from the center, which should not entail restrictions on the basic freedom of local authorities [Marková 2010: 133-134].

At the present time, issues of organizing local self-government in the territory of the Russian Federation are regulated by the Act no. 131-FZ/2003. It follows from the content of this law 
that local self-government is understood as a form of exercise by the people of their power, which ensures independent and responsible solution of local issues by the population directly and through local self-government authorities.

It is evident that consolidation of the ability of municipalities to independently solve local issues created a necessity of fi nancing this process. This means that municipalities must have their own budget, which will be replenished with certain revenues and spent accordingly for defined purposes.

In 2001, the Russian Government approved the Program for the development of budget federalism in the Russian Federation for the period up to 2005 [Act no. 584/2001]. It stated that the level of decentralization of budgetary resources in Russia is almost equal to most federal states, but formally retains an extremely high centralization of tax and budgetary powers. Therefore, one of the main tasks of the Program was the formation and development of objective and transparent fi nancial support mechanisms for local budgets.

\section{Forms and conditions of providing inter-budget transfers in the Russian Federation}

With the adoption of the Budget Code of the Russian Federation in 1998, it was established that the budget system of the Russian Federation includes the federal budget, budgets of regions and local budgets. The existence of these elements of the system has a constitutional basis and is associated with the federal structure of Russia, as well as the recognition of the autonomy of local self-government.

It should be noted that the federal model of the budget system in Russia was preceded by the model of the state budget [Komyagin 2017: 253], in which all budgets (of the Union republics, district, settlement, city, and others) were included in the unified state budget of the USSR. According to M. Piskotin, the integration of all independently created budgets in the territory of the USSR into the unifi ed state budget of the USSR was explained by many reasons, primarily the socio-economic system of the country, as well as the need for the greatest centralization of the country's financial resources [Piskotin 1971: 71].

However, nowadays in Russia another variant of the budget system is used: the budget of the center (the Federation) and the budgets of the regions are created independently, exist separately, and are not united into a unified budget [Sokolova 2019]. The situation is similar with local budgets. They have financial autonomy. 
The fi nancial autonomy of municipalities is also characteristic of unitary states, for example, the Republic of Lithuania, Poland and Slovakia. Thus, the budget of a municipality is independent and not included in the state budget of the Republic of Lithuania, as follows from part 1 of Article 127 of the Constitution of the Republic of Lithuania [Sudavicius 2017: 57].

The independence of each of the budgets of the budget system of the Russian Federation does not preclude the interaction of budgets with each other, moreover, it is necessary to ensure the balance of budgets [Sokolova 2019].

This situation is not accidental. Analysis of the budget legislation of the Russian Federation allows us to conclude that the main revenues are concentrated the federal level and then at the level of regions. In this regard, the third level of the budget system of the Russian Federation, namely, local budgets is constantly short in funds to cover the expenditures of solving local issues.

Moreover, local self-government authorities have the right to solve not only these issues, but also other issues that are referred to the competence of other levels of government. Also, the Russian Federation or a region has the right to delegate its powers to the local level.

It turns out that municipalities constantly need financial support from the state not only to solve local issues, but also to ensure the delegated or accepted powers of other levels of government. And this financial support can be expressed in various forms.

In many countries of the world (the Czech Republic, the Republic of Lithuania, Poland, Slovakia, etc.) the provision of financial support by the state to local self-government is already a well-established practice.

For example, according to the Constitution of the Republic of Poland of 1997, the base of budget revenues of territorial self-government units consists of three categories of funds: own revenues, general subvention and targeted grants [Pomorska 2010: 109].

In the Czech Republic municipalities receive subsidies from the state and regional budgets, and also contribution from the state budget for the performance of delegated tasks [Act no. 128/2000 Sb., Act no. 250/2000 Sb.].

In Slovakia local budgets receive the following types of $\mathrm{fi}$ nancial support: subsidies from the state budget to cover the expenditures of transferred performance of state administration, additional subsidies from the state budget, special-purpose subsidies from the budget of the higher territorial unit or from the budget of another municipality [paragraph 5 Act no. 583/2004 Sb.]. 
In the Russian Federation, there is also a complicated system of inter-budget relations, part of which is the relationship for the provision of inter-budget transfers. The particularity of these relations is that the Russian Federation enters into relations with regions, and regions with municipalities.

Inter-budget transfers account for a signifi cant part of local budget revenues. According to the Ministry of Finance of the Russian Federation, in the total amount of local budget revenues in 2018 , the share of inter-budget transfers without including the return of balances (including subventions) is $64.5 \%$ or $2,737.6$ billion rubles (in $2017-63.7 \%$ or $2,451.5$ billion rubles). Their provision to local budgets is primarily due to the economic insolvency of most territorial entities caused by the uneven distribution of economic potential [Ivliev 2010: 4].

The definition of "inter-budget transfers" appeared in Article 6 of the Budget Code of the Russian Federation only as a result of the adoption of the Act no. 120-FZ/2004. Nowadays they are understood as funds provided by one budget of the budget system of the Russian Federation to another budget of the budget system of the Russian Federation. However, it is not clear from this definition which budget can provide funds to another budget.

Chapter 16 of the Budget Code of the Russian Federation is devoted to inter-budget transfers. Insignifi cant changes to the Code were dictated by the unfolding practice of law enforcement. The last significant changes, including those specifying the regulation of interbudget transfers, were made by the Act no. 307-FZ/2019.

It is necessary to understand, firstly, from what budget municipalities can receive financial support, and, secondly, in what forms it can be expressed. Let's look the example of the budget of such a municipality as a municipal district. Analysis of the provisions of the Budget Code of the Russian Federation allows us to identify the following levels of budgets that provide funds to a budget of a municipal district:

1. from the regional budget - in the form of grants, subsidies, subventions, and other inter-budget transfers;

2. from the local budget of urban and village settlements that are part of the municipal district - in the form of subsidies and other inter-budget transfers;

3. from the budget of one municipal district to the budget of another municipal district - in the form of subsidies (so-called «horizontal» subsidies). 
As for the federal budget, it cannot directly provide inter-budget transfers to municipalities. At the same time, it is possible to allocate funds to the budgets of the regions in order to further transfer them to local budgets. These inter-budget transfers can be called «transit» transfers. They can be provided in the form of grants, subsidies, subventions, and other inter-budget transfers.

The particularity of the Russian budget legislation in terms of regulating inter-budget transfers is that each municipality applies for receiving them. However, for municipalities with a certain level of grants in their budget, a set of conditions is required to observe. In other words, we are talking about granted municipalities.

Primarily, let's look at the general conditions that are required to observe when granted municipalities receive any inter-budget transfer.

In 2007, when the law on amendments to the Budget Code of the Russian Federation was adopted, the Russian Government explained that the introduction of additional conditions for providing inter-budget transfers to granted and highly granted municipalities is carried out in order to implement the principles of transparency of municipal finances, which require practical realization in accordance with the Budget Message of the Federal Assembly of the Russian Federation for that year [explanatory note to the draft Act no. 390549-4].

These conditions are divided into three categories. The division criterion is the percentage of grants from other budgets of the budget system of the Russian Federation and (or) tax revenues under additional standards in relation to all local budget revenues. It is obvious that this criterion is a guide to the state of the dependence of the municipal budget on non-targeted funds received from another level of the budget system of the Russian Federation.

It should be observed that local budget revenues are not taken into account in full. Subventions must be excluded from all local budget revenues. Moreover, if we are talking about a municipal district or a settlement that is a part of it, other inter-budget transfers provided by an agreement between them are also subject to exclusion from revenues. This change was recently introduced by the Act no. 307-FZ/2019. It is obvious that the procedure for calculating this percentage has been toughened, and now a noticeably larger number of municipal districts and settlements may fall into the category of "granted" municipalities. This percentage is calculated for two of the last three financial years.

The first category includes municipalities where this percentage is more than 5 percent, but does not exceed 20 percent inclusive. For them restrictions are set in the form of the 
impossibility of exceeding standards of formation of expenditures established by the highest body of executive power of regions for labour remuneration of deputies, elected officials of local government exercising the powers on a constant basis, municipal officers and (or) the allowance of the local authorities.

For the second category of municipalities, the specified percentage is higher than 20, but up to 50 percent inclusive. For them restrictions are set in the form of the impossibility to establish and fulfill expenditure commitments that are not connected with the resolution of issues reserved by the Constitution of the Russian Federation, federal laws, laws of regions to the powers of the relevant local self-government authorities. In other words, these budgets have the ability to spend budgetary funds exclusively on local issues.

Finally, the third category of municipalities has a threshold of more than 50 percent. Obviously, the most severe restrictions should be for these municipalities. Firstly, the restrictions established for the two groups listed above are in force for them, and, secondly, a set of additional measures.

On the one hand, these measures are intended to control the local budget adopted for the next financial year and planning period, even when it is adopted. In this regard, local government is obligated to submit to the highest body of executive power of regions the necessary documents and materials for the preparation of a statement of compliance of the draft budget are submitted to the local representative authority under the requirements of the budgetary legislation of the Russian Federation. On the other hand, we are talking about control the budget that has already been executed. Therefore, a rule has been established to conduct an audit of the annual local budget implementation report by regional control and accounting authorities or state financial control authorities that are regional executive authorities at least once every two years. It turns out that the region receives some control powers to prevent the adoption of a budget containing possibly excessive expenditures, and, on the other hand, to check the legality and efficiency of the use of budget funds.

All of the above restrictions begin to apply from the next financial year.

Analysis of these conditions for the provision of inter-budget transfers allows us to say that the financing of granted municipalities from the regional budget or the federal budget does not stop. At the same time, these measures in a certain way either limit the possibility of establishing or increasing certain types of expenditures, or are associated with increased control by the regional authorities. It can be said that these measures restrict the financial autonomy of local self-government in a certain way. Although the Government of the Russian 
Federation when working out the draft Federal law, which amended the Budget Code of the Russian Federation in terms of establishing these conditions, applied a lesser sentence expression, noting that these measures are aimed at strengthening financial discipline when using financial support[(explanatory note to the draft Act no. 364850-3].

An important legislative rule that confi rms the right of each municipality to receive interbudget transfers from the regional budget in one form or another is the proscription of establishing the possibility of receiving them depending on the performance indicators of the activities of local self-government authorities.

Therefore, any form of inter-budget transfer is provided exclusively by an objective method.

This practice is also known in the legislation of other European countries. For example, from the Act of the Republic of Lithuania no. VIII-385/1997 it follows that the amount of funds allocated to equalize differences in the structure of expenditures of municipalities is also determined by objective factors and does not depend on the activities of municipalities. These factors include demographic, social, and other indicators that infl uence objective changes in differences in structures of municipal expenditures and the signifi cance of these indicators.

It should be noted that for a little over 10 years, the main condition for providing inter-budget transfers (with the exception of subventions) was the need for the relevant local authorities to comply with the budget and tax legislation of the Russian Federation. However, this rule does not apply from 2020.

\section{Subvention as a main form of inter-budget transfers to local budgets}

The main form of inter-budget transfers is a subvention. According to the Ministry of Finance of the Russian Federation, the share of subventions in the total amount of inter-budget transfers received by local budgets in 2018 was a little over 50 percent.

Delegation of powers to the municipal level is also peculiar to other European countries.

For example, Article 14 of the Act of the Republic of Lithuania no. I-533/1994 stipulates that state functions are delegated to municipalities by this act and other acts. For this purpose they receive special targeted grants [Article 5 Act no. VIII-385/1997].

Section III of the Act of the Czech Republic no. 128/2000 Sb., in turn, is dedicated to the delegated powers of municipalities. One of the paragraphs stipulates that municipalities will 
receive a contribution from the state budget to fulfil tasks within the delegated competence. As H. Marková notes, the delegated competence of local government units is essentially a decentralized state administration entrusted to the municipal authorities at law [Marková 2010: 137].

The legislation of Slovakia also provides for the possibility for the state to delegate its powers to municipalities with subsidies to cover the expenditures of their performance [Act no. 583/2004 Sb.].

The right to delegate powers to local self-government authorities also follows from the above-mentioned European Charter of Local Self-Government. Thus, according to part 3 of Article 4 of the Charter, «public responsibilities shall generally be exercised, in preference, by those authorities which are closest to the citizen. Allocation of responsibility to another authority should weigh up the extent and nature of the task and requirements of efficiency and economy». According to M. Radvan's fair statement, if there is the growing number of tasks and thus the responsibility of municipalities and regions to accomplish these tasks, there must be an increase of the financial resources [Radvan 2017: 10].

Subventions to local budgets are defined as targeted funds allocated to them if they are entrusted with fulfilling expenditure commitments assigned to the higher budget [Komyagin 2017: 268].

A subvention can be allocated to the local budget both when the Russian Federation delegates powers and when the region delegates powers. However, if we are talking about the powers of the Russian Federation, local budgets receive funds for their financial support from the federal budget not directly, but through the regional budget.

The procedure for determining the total amount of subventions for the exercise of delegated powers and the criteria for disposition of the total amount of such subventions among municipalities are established at the regional legislative level.

The disposition of subventions on municipalities that are part of the region is based on objective indicators, for example, in proportion to the population (individual population groups), consumers of relevant state (municipal) services, as well as a number of other indicators.

The use of objective criteria in determining the amount of subventions is also peculiar to other states. For example, in Annex 8 to the Act of the Czech Republic no. 355/2019 Sb. it is established that the amount of the contribution for the performance of state administration depends on the amount of delegated powers for the performance of state administration and 
the number of residents. Various coefficients are also used. However, an analysis of the laws of the Czech Republic on the state budget for previous years $(2018,2019)$ allows us to state that the criteria for calculation have not changed.

An important guarantee of receiving funds to finance delegated powers is the rule that the use of indicators that characterize their own revenues of local budgets in the disposition of subventions to local budgets is not allowed.

\section{Subsidy as a form of inter-budget transfers to local budgets}

Another form of inter-budget transfers, which ranks second in the total structure of interbudget transfers received by local budgets (25.2 percent for 2018), is a subsidy.

A subsidy, like a subvention, is a targeted financial support. However, it has a fundamental difference from it, which is exactly the nature of the target. Financial support in the form of a subsidy is aimed at co-financing expenditures related to the exercise of the powers of local self-government authorities on local issues.

Co-financing assumes that the local budget independently finances its own powers, and the state (Federation or region) only partially helps it in this. It turns out that a subsidy can be received from the regional budget and from the federal budget through the regional budget.

The right to receive subsidies from two higher levels of the budget (state and regional) is also stipulated in the Act of the Czech Republic no. 250/2000 Sb. (paragraph 7). According to paragraph 19 of the Act of the Czech Republic no. 218/2000 Sb., subsidies from the state budget to the budgets of the municipalities are provided through the regions in which the relevant municipality is located, unless otherwise stipulated in this or a special law.

Article 42 of the Act of Poland of 13.11 .2003 as well as Russian legislation establish the right of local governments to receive targeted subsidies to finance their own tasks. The law lists the purposes for which these subsidies can be provided, some of which are related to the development of education and sports. In Polish legislation we are also exclusively talking about co-financing of solving local tasks.

The main condition that the Russian legislator sets to receive the form of inter-budgetary transfers is in the budget of the municipality budget appropriation for fulfilling expenditure commitments of the municipality, for the purposes of co-financing of which a subsidy is 
provided to the extent that is necessary for their fulfillment, including the amount of the subsidy planned for the provision from the regional budget. However, the issue of the specific amount of the municipality's own budget funds is regulated by a normative legal act of the highest regional body of executive power.

Polish legislation contains a similar rule. But in contrast to the Russian Federation, the abovementioned Act of Poland of 13.11.2003 centrally establishes the amount of local government's own resources for the fulfillment of the relevant task. It constitutes at least 50 percent of the planned expenditures for fulfilling the task. If this rule is not met, and the subsidy is received, the local budget must return the sum of the subsidy in the amount determined as the difference between the sum of the subsidy received and the sum of expenditures incurred from its own funds. In our opinion, this practice of legal regulation, when the issue of the amount of own funds of local budgets for the fulfilling of expenditure commitments is solved centrally and is the same for all municipalities, is positive.

Unlike grants and subventions, regulations establishing general requirements to the formation, provision and disposition of subsidies from the regional budget to local budgets and the procedure for determining and setting limits on the level of co-financing by region (in percent) of the amount of expenditure commitments of a municipality are established by a normative legal act of the highest regional body of executive power.

Moreover, this highest body of executive power adopts a normative legal act for each type of subsidy. It turns out that at the level of the region there is a general and special legal regulation of the procedure and conditions for provision of subsidies to municipalities.

It is interesting that before the adoption of the Act no. 307-FZ/2019, this issue was resolved both at the legislative level of the region and by the highest body of executive power of the region in the relevant normative legal act.

The subsidy is provided pursuant to an agreement between the region and the municipality. It contains the obligations of the municipality to fulfill expenditure commitments, for the purpose of co-financing of which a subsidy is provided, and responsibility for failure to fulfill the obligations stipulated in the said agreement.

The list of subsidies to be provided to municipalities from the regional budget, as well as their disposition among local budgets, is approved by the law on the budget of this region. Like any form of inter-budget transfer, the amount of the subsidy is specified in the law of the region on the budget for the ensuing financial year and planning period. 


\section{Grant as a form of inter-budget transfers to local budgets}

According to the Ministry of Finance of the Russian Federation, in the total structure of inter-budget transfers received by local budgets in 2018, grants are in the third place after subventions and subsidies, signifi cantly inferior to them in amount.

The definition of grants is given in Article 6 of the Budget Code of the Russian Federation. They are understood as inter-budget transfers that are provided on a free and non-repayable terms without establishing the directions of their use. In other words, this is non-targeted financial support.

However, this is not to say that grants are provided to each municipality in arbitrary amount. As with any form of inter-budget transfer there are objective criteria for providing them to one municipality or another.

According to the budget legislation of the Russian Federation, there are three types of grants: a fiscal equalisation grant, a grant to support measures to provide budget balance, and other grants. The most common type of grant is a fiscal equalisation grant (in 2018, the share of this type of grant in the total amount of grants provided to local budgets was 74 percent). Therefore, we will try to define the main specifics of this particular type of grants.

It is obvious from the name that the state, represented by the region, seeks to equalize the financial situation between different municipalities and adjust them to a certain level. In the budget legislation of the Russian Federation, the term is used for this purpose - the standard of an estimated fiscal equalisation.

It is interesting that the procedure for determining the standard of an estimated fiscal equalisation of municipalities, as well as the procedure for allocating grants, is in a decentralized manner. This means that each region independently resolves these issues by adopting relevant law.

However, when determining this standard, regions often use the methodology for allocating a fiscal equalisation grant for regions, approved by the Government of the Russian Federation [Act no. 670/2004].

According to this methodology, the basis for calculating fiscal capacity is two standards, the index of taxable capacity and the index of budget expenditures, in our case, of a municipality. The index of taxable capacity of a municipality is essentially the amount equal to the ratio of tax income accrue to one resident of this municipality to the regional average tax income accrue to one resident of an average municipality in the territory of the relevant region. 
The index of budget expenditures of the municipality, in simple terms, is the amount equal to the ratio of notional amount of expenditure of municipalities of the relevant region for the provision of a standard set of municipal services to notional amount of expenditure of average municipal for the provision of the same standard set of municipal services [Ilyin 2015: 158]. At the same time, according to the Budget Code of the Russian Federation, the cost of services is influenced by a number of objective factors, such as the structure of the population, socio-economic, climatic, geographical, and others.

The Republic of Lithuania also provides for the allocation of two types of grants from the state budget to municipalities. The first is a grant to equalize the municipal income tax from the population. The second is a grant to compensate for differences in the structure of municipal expenditures generated by objective factors independent of municipal activity. At the same time, the calculation of the first type of grants is also based on a certain tax revenue per capita. In this case the revenue from income tax per capita in a particular municipality is taken and compared with the average revenue from income tax per capita in all municipalities [Act no. VIII-385/1997].

At the same time, when calculating the second type of grants, a coefficient is used that refects demographic, social and other indicators that infl uence the structure of expenditures. This coefficient has a certain similarity to the index of budget expenditures of municipalities in the Russian Federation.

In Poland, a transfer provided from the state budget to self-government units, called a general subvention, bears some similarities to the Russian grant. As A. Pomorska notes, it is characterized by three essential traits: generality, obligatoriness and guaranteeing territorial self-government units a certain freedom in choosing the purposes and intents of these funds. This transfer is also determined on the basis of objective criteria.

According to the Act of Poland of 13.11.2003, the general subvention has a complex structure. First, this subsidy, based on the example of the main unit of local government - commune (gmina), consists of compensatory and balancing parts. In turn, the compensatory part includes the basic and additional amounts. The index of tax revenue per capita is also used to determine the amount of the base amount of the compensatory general subsidy allocated to communes (Article 20). This article lists the taxes that are taken into account in this calculation. While the amount of housing allowances per capita is used to determine the balancing part.

The essence of the fi scal equalisation grant is that a certain average level of the fiscal capacity of municipalities of the relevant type on the territory of a particular region is calculated. 
Municipalities below this level claim to receive a grant. Those who have a higher level do not have the right to receive this grant. The situation may change every year. But it is obvious that almost every municipality in the region annually claims to receive grants of this type.

As for the specifi c amount for each municipality, it is approved in the law on the regional budget for the ensuing fi nancial year and planning period. The legislation of both Poland and the Republic of Lithuania has essentially similar rules [Article 20 Act of Poland of 13.11.2003, Article 5 Act no. VIII-385/1997].

\section{Conclusion}

The analysis of the issue of financial support provided by the state to municipalities both on the territory of the Russian Federation and on the territory of a number of European countries (the Czech Republic, the Republic of Lithuania, and Poland) allows us to say about their large financial dependence on the state.

According to M. Radvan, due to the dependence of municipalities on the state budget, it is impossible to talk about their real economic autonomy [Radvan 2017: 7].

A similar point of view is held by E. Juchniewicz, analyzing the fiscal autonomy of municipalities in Poland. As the author notes, when municipalities are subsidized by the state they lose their fi nancial autonomy [Juchniewicz 2017: 34]. A. Pomorska is also of the opinion that there is a lack of financial resources available to territorial self-government units in Poland in comparison with the amount and nature of the tasks they perform [Pomorska 2010: 109].

The obvious dependence of local budgets on the federal and regional budgets requires clear legislative regulation of relations on the provision of inter-budget transfers.

There is no denying the fact that in the Russian Federation budget legislation on this issue is subject to periodic modernization. The previously reviewed Act no. 307-FZ /2019 once again confirmed that the state should strive to regulate relations on the provision of inter-budget transfers, including to local budgets, as much as possible.

However, there are some comments on legal regulation.

First of all, all methodologies for determining municipalities applying for certain inter-budget transfers, their amount, and the procedure for providing them are regulated by regional laws or even normative legal acts of the highest regional body of executive power. This clearly 
indicates the decentralization of legal regulation of the sphere of budget relations under consideration. Of course, some general principles are enshrined in the Budget ode of the Russian Federation. In particular, the objectivity of criteria that affect the right to receive inter-budget transfers and their amount. This means that it is impossible to determine their amount depending on criteria such as the effectiveness of activity of the municipalities or the amount of their own revenues from local budgets. However, in our opinion, the legal regulation of at least the criteria for providing inter-budget transfers should be more centralized.

In our opinion, the general conditions for providing inter-budget transfers established by the Budget Code of the Russian Federation limit the financial autonomy of municipalities in a certain way. This applies to granted municipalities.

Moreover, restrictions are increased when the level of grants increases. Perhaps these measures can be considered forced but at the same time they stimulate the activities of municipalities for more careful budget planning and efficient spending of budget funds.

\section{References}

1. Dabla-Norris, E.: The challenge of fiscal decentralization in transition countries, Comparative Economic Studies no. 48 (2006).

2. Ilin, A.: Pravovaya priroda dotacij na vyravnivanie byudzhetnoj obespechennosti (Legal nature of fiscal equalisation grants), Rossijskij yuridicheskij zhurnal (Russian legal journal) no.5 (2015).

3. Ivliev, I.: Pravovoe regulirovanie mezhbyudzhetnyh transfertov (Legal regulation of inter-budget transfers), Moscow, 2010.

4. Komyagin, D.: Byudzhetnoe pravo (Budget Law), Moscow: Publishing house of the higher school of Economics, 2017.

5. Juchniewicz, E.: The principle of fiscal local autonomy in the light of Polish Constitution, Financial Law Review no.2(2) (2017).

6. Marková, H.: Municipalnaya sobstvennost i byudzhetnye otnosheniya (Municipal property and budgetary relations) in: Karaseva (Sentsova), M. et al. (eds.): Tax and budget law: modern problems of property relations, Voronezh: Publishing house of Voronezh state University, 2012.

7. Marková, H.: Territorialnye municipalnye obrazovaniya, ih imushchestvennaya i finansovaya samostoyatelnost (Territorial municipalities, their property and financial autonomy) in: Karaseva (Sentsova), M. et al. (eds.): Modern problems of financial and tax law in Central and Eastern Europe, Voronezh: Publishing house of Voronezh state University, 2010.

8. Piskotin, M.: Sovetskoe byudzhetnoe pravo (osnovnye problemy) (Soviet budget law (main problems), Moscow: Legal literature, 1971. 
9. Pomorska, A.: Glavnye barery v processe ogranicheniya raskhodov gosudarstvennogo byudzheta $\checkmark$ Polshe (Main barriers in the process of limiting state budget expenditures in Poland) in: Karaseva (Sentsova), M. et al. (eds.): Modern problems of financial and tax law in Central and Eastern Europe, Voronezh: Publishing house of Voronezh state University, 2010.

10. Radvan, M.: Article 9 of the European Charter of Local Self-Government in the Czech Republic, Financial Law Review no. 2(4) (2017).

11. Rodriguez-Pose,A., Ezcurra, R.: Does decentralization matter for regional disparities? Acrosscountry analysis. (https://eprints.Ise.ac.uk/33244/1/sercdp0025.pdf)

12. Sokolova, E. (ed.): Finansovoe parvo (Financial law), Moscow: Prospect Publ., 2019.

13. Sokolova, E.: Pravovoe regulirovanie finansovoj deyatelnosti gosudarstva i municipalnyh obrazovanij (Legal regulation of financial activities of the state and municipalities), Moscow: Jurisprudence, 2019.

14. Sowiński, T.: The process of municipalization of the state in a spirit of the idea of subsidiarity and in accordance with the European Charter of Local Self-Government at the example of Poland from 1990 to 2015, Financial Law Review no.2(4) (2017).

15. Sudavicius, B.: Municipalnye obrazovaniya kak subekty nalogovogo administrirovaniya v Litovskoj Respublike (Municipalities as the subjects of tax administration in the Republic of Lithuania), Pravoprimenenie (Law Enforcement Review) no.2 (2017).

\section{Legal acts}

1. European Charter of Local Self-Government of 1985 by the Act no. 55-FZ/1998.

2. Act of the Czech Republic no. 128/2000 Sb., on municipalities (as amended).

3. Act of the Czech Republic no. 250/2000 Sb., on budgetary rules of territorial budgets (as amended).

4. Act of the Czech Republic no. $218 / 2000$ Sb., on budgetary rules and amending certain related laws (budget rules) (as amended).

5. Act of the Czech Republic no. 355/2019 Sb., on the state budget for 2020.

6. Act of Poland of 13.11.2000, on local self-government revenues (as amended).

7. Act of the Republic of Lithuania no.l-533/1994, on local self-government (as amended).

8. Act of the Republic of Lithuania no. VIII-385/1997, on methodology for determining revenue of municipal budgets of the Republic of Lithuania (as amended).

9. Act of Slovakia no. 583/2004 Sb., on budget rules of territorial self-government and on amendments to certain laws (as amended).

10. Act no. 1550-1/1991, on local self-government in the Russian Federation.

11. Act no. 145-FZ/1998, the Budget Code of the Russian Federation (as amended).

12. Act no. 131-FZ/2003, on general principles of organizing local self-government in the Russian Federation (as amended).

13. Act no. $120-F Z / 2004$, on amendments to the Budget code of the Russian Federation in terms of regulating inter-budget relations. 
14. Act no. 307-FZ/2019, on amendments to the Budget code of the Russian Federation in order to improve inter-budgetary relations.

15. Act no. 584/2001, on the program of development of budget federalism in the Russian Federation for the period up to 2005.

16. Act no. $670 / 2004$, on disposition of fiscal equalisation grant of subjects of the Russian Federation (as amended).

17. Explanatory note to the draft Act no. 364850-3. (https://sozd.duma.gov.ru/bill/364850-3)

18. Explanatory note to the draft Act no. 390549-4. (https://sozd.duma.gov.ru/bill/390549-4)

19.https://www.minfin.ru/common/upload/library/2019/06/main/Rezultaty_provedeniya_ monitoringa_mestnykh_budzhetov_za_2018_god.pdf 